\title{
Sorption Characteristics of Bulgarian Penny Buns (Boletus Edulis)
}

\author{
Albena Durakova, ${ }^{1, *}$ \\ ${ }^{1 *}$ Department of Process Engineering, University of Food Technologies - Plovdiv, 26 Maritza Blvd. \\ BG-4002 Plovdiv, Bulgaria
}

\begin{abstract}
The present study determined the sorption characteristics of Bulgarian penny buns (Boletus) for eight water activities in the $10 \%-90$ $\%$ range and at three temperatures, of $10{ }^{\circ} \mathrm{C}, 25{ }^{\circ} \mathrm{C}$ and $40{ }^{\circ} \mathrm{C}$. The coefficients of the modified Oswin, Chung-Pfost, Halsey and Henderson models were obtained statistically. The modified Halsey model is recommended as a description of adsorption and desorption isotherms since it corresponds to the criteria for model assessment and suitability. Via BET model linearization, the values of the monolayer moisture content for water activity of aw $>0.5$ and temperatures of $10{ }^{\circ} \mathrm{C}, 25{ }^{\circ} \mathrm{C}$ and $40{ }^{\circ} \mathrm{C}$ were established. The approximate physico-chemical composition of Bulgarian penny buns (Boletus) - moisture content $-10.80 \%$, protein $32.23 \%$, carbohydrate $-0.99 \%$, fat $-6.62 \%$, ashes $-6.20 \%$ - was also determined.
\end{abstract}

Key words: penny buns (Boletus), physico-chemical parameters, sorption characteristics

\footnotetext{
* Corresponding author: aldurakova@abv.bg
} 


\section{Introduction}

The wild mushroom penny bun (Boletus Edulis) grows in deciduous and coniferous woods and plains. It is among the most popular collected mushrooms in Bulgaria due to its excellent taste and high nutritive value. Penny buns are rich in carbohydrates, fats, minerals, vitamins, and fibre. They contain up to $35 \%$ of essential proteins including glutamine, arginine, leucine and tyrosine. Penny buns are also high in PP vitamins, nicotinic acid, various macro-elements and trace elements. The consumption of penny buns supplies the body with B, C, E and D vitamins.

Penny buns are among the mushrooms with the greatest amount of amino acids, which makes them extremely suitable for vegetarian diets, as a substitute for meat. Vitamin-rich penny buns are an integral part of healthy diets. The interior of these mushrooms is easily assimilated by the gastrointestinal tract, absorbs toxins and expels them from the organism.

Traditionally, European cuisine regards penny buns as being among the most delicious wild-grown mushrooms. Due to its ability to accumulate selenium, the penny bun is a natural source of organic selenium, which makes it useful for the enrichment of various food products with micronutrients. The deficiency of selenium in the human organism can lead to many health problems [1-3]. Selenium is crucial for testosterone production and the formation and normal development of sperm cells (spermatozoa) [4]. In contrast to other edible plants, both wild-grown and cultivated mushrooms can assimilate and accumulate not only selenium but also other toxic components, such as mercury, arsenic, lead, cadmium, chrome, copper, iron, nickel, zinc, etc. [5]. Therefore, the dosage of the mushroom as an ingredient has to be very accurate since overdosages may be poisonous for human beings [6].

The literature review did not reveal data on the sorption characteristics of wild Bulgarian penny buns (Boletus Edulis), which motivated our research.

\section{Materials and Methods}

\subsection{Materials}

The present study focuses on wild Bulgarian penny buns (Boletus Edulis) from the Rhodope region of Byala Cherkva which were dried at atmospheric conditions and ground into powder.

The packaging - coextruded barrier film with copolymer covering for heat sealing, to be used in the food and flavour industry - was provided by the «ET - Ilko Tyanev Ita Plast» company.

\subsection{Methods}

Moisture, $(\%)$ of the products studied - standard method via drying of $5 \mathrm{~g}$ of flour at $105{ }^{\circ} \mathrm{C}$ to constant weight, according to AOAC, 1990 [7];

Protein - Direct Kjeldahl method analysis (determination of nitrogen content/ nitrogen determination method) - Regulation (EC) №152/2009 [8];

Fat content, (\%) - Soxhlet method via solvent extraction with petroleum ether. BSS 6997:1984 [9];

Carbohydrate - BSS 7169:1989 [10];

Ash, (\%) - The method used for the determination of ash content in flour is according to ICC Standard №104/1 "Determination of Ash in Cereals and Cereal Products” [11];

Energy value - Regulation 1169:2011, Appendices IVX ; XV [12]. 
Determination of microbiological parameters:

Determination of Escherichia coli, according to BSS EN ISO 16649-2:2014 [13];

Determination of Salmonella sp., according to BSS EN ISO 6579-1:2017 [14];

Determination of coagulase-positive staphylococci, according to BSS EN ISO 68881:2005 [15];

Determination of total number of mesophilic aerobic and facultative anaerobic bacteria, according to BSS EN ISO 4833-1:2014 [16];

Determination of mould and yeast, according to BSS EN ISO 21527-2:2011 [17].

Grinding of experimental raw material - laboratory grinder Tefal GT110838;

Flour particle size - The determination of the size of flour particles via sieve analysis was conducted by means of "ProMel LP - 200" sieve shaker, according to BSS $754-80$ "Milled Products. Regulations for Sampling and Testing Methods". On the basis of the preliminary analysis, the set of sieves was determined, as well as their size. A sample of $100 \mathrm{~g}$ was sieved by the apparatus for ten minutes.

The sorption isotherms were studied with the help of the static gravimetric method recommended for food products by Project COST 90. In order to assess the adsorption and desorption capacity of the product, the latter was subjected to preliminary forced drying and moistening. These processes took place in desiccators - above distilled water to achieve a maximally saturated moist medium and above $\mathrm{P}_{2} \mathrm{O}_{5}$ to achieve a maximally dry environment, respectively. The samples remained in the desiccators for 10 days. After the determination of the moisture content obtained via the standard drying method, they were weighted as per $1 \pm 0.02 \mathrm{~g}$ in weighing bottles. The weighing bottles were placed in hygrostats above saturated solutions of 8 salts $\left(\mathrm{LiCl}, \mathrm{MgCl}_{2}, \mathrm{~K}_{2} \mathrm{CO}_{3}, \mathrm{NaBr}, \mathrm{CH}_{3} \mathrm{COOK}\right.$, $\mathrm{NaCl}, \mathrm{KCl}, \mathrm{MgNO}_{3}$ ) maintaining constant water activities above the surface, in the $10 \%$ $90 \%$ range [18]. For high water activities, $\left(a_{w}>0.70\right)$ in hygrostats thymol crystals were introduced to prevent against microbiological deterioration. The hygrostats were tempered in thermostats at temperatures of $10{ }^{\circ} \mathrm{C}, 25^{\circ} \mathrm{C}$ and $40{ }^{\circ} \mathrm{C} \pm 0.2{ }^{\circ} \mathrm{C}$. When equilibrium was reached within 20 days, the moisture content of each sample was determined via a drying method $\left(105^{\circ} \mathrm{C}\right.$ for $\left.24 \mathrm{~h}\right)$ as a mean value of three iterations [7].

All analyses were conducted in triplicate runs.

The experimentally obtained sorption isotherms were described with the help of the modified models recommended for products of plant origin in Standard 245D of the American Society of Agricultural Engineers (ASAE) [18]:

$$
\begin{array}{ll}
\text { Modified Chung-Pfost } & a_{\mathrm{w}}=\exp \left[\frac{-A}{\mathrm{t}+B} \exp (-C M)\right] \\
\text { Modified Halsey } & a_{\mathrm{w}}=\exp \left[\frac{-\exp (A+B t)}{M^{C}}\right] \\
\text { Modified Oswin } & M=(A+B t)\left(\frac{a_{\mathrm{w}}}{1-a_{\mathrm{w}}}\right)^{C} \\
\text { Modified Henderson } & 1-a_{\mathrm{w}}=\exp \left[\left(-A(t+B) M^{C}\right]\right.
\end{array}
$$

Model suitability criteria were the values of mean relative error P [\%] and standard error (SEM) [19, 20]:

$$
P=\frac{100}{N} \sum\left|\frac{M_{\mathrm{i}}-\hat{M}_{\mathrm{i}}}{M_{\mathrm{i}}}\right|
$$




$$
\begin{aligned}
& S E M=\sqrt{\frac{\sum\left(M_{\mathrm{i}}-\hat{M}_{\mathrm{i}}\right)^{2}}{\mathrm{~d} f}} \\
& e_{\mathrm{i}}=M_{\mathrm{i}}-\hat{M}_{\mathrm{i}}
\end{aligned}
$$

where $M_{i}$ and $\widehat{M}_{i}$ are the experimentally obtained equilibrium moisture content value as calculated by the model, $\mathrm{N}$ being the number of test points and $\mathrm{d} f$ being the degree of freedom (number of test points minus number of constant values in the model).

To calculate monolayer moisture content, we used the linear transform on the basis of the BET (Brunauer-Emmett-Teller) model [21].

BET

$$
M=\frac{M_{m} C a_{w}}{\left(1-a_{w}\right)\left(1-a_{w}+C a_{w}\right)}
$$

where $M_{m}$ is monolayer moisture content, \% d.b.; $C$ - constant value.

\section{Results and Discussion}

Prior to subjecting the mushrooms to laboratory analyses, they were dried at atmospheric conditions and vacuum-packaged in packaging from coextruded barrier film with copolymer covering for heat sealing used in the food and flavour industry.

Following the acceptance of the raw material for analysis, the latter was ground by a laboratory grinder Tefal GT110838 to achieve powdery texture and particle size determined by sieve analysis. The sieve analysis determining flour particle size was conducted by means of "ProMel LP - 200" sieve shaker. On the basis of the preliminary sieve analysis of the initial sample, the set of sieves was established as well as the tolerance in mesh size. This allowed for the formation of fractions with specific particle size. Particle size is an important characteristic and a major factor in choosing storage conditions for powdery products [22, 23]. The granulometric composition of the products gives information concerning the distribution of particles in percentages with respect to total mass. The results obtained from the analysis are shown in Table 1

Table 1. Granulometric composition of flour from Bulgarian Penny Buns (Boletus Edulis)

\begin{tabular}{|c|c|}
\hline Particle Size & Amount of Particles, $\%$ \\
\hline $1000 / 600$ & 3.4 \\
\hline $600 / 400$ & 5.6 \\
\hline $400 / 200$ & 27.9 \\
\hline $200 /$ & 63.1 \\
\hline
\end{tabular}

On the basis of the analyses and the results obtained, we can point out that, for the most part, the fractions had particle sizes between $400 \mu \mathrm{m}$ and $200 \mu \mathrm{m}$, as well as below $200 \mu \mathrm{m}$. The percentage of the fractions below $200 \mu \mathrm{m}$ was most significant $-63.1 \%$. The data show that the product is extremely fine, which makes it suitable as an enriching ingredient of various food products.

The physico-chemical characteristics and the microbial contamination are important parameters for every food product because they are informative for both the manufacturer and the consumer. The physico-chemical analysis of the flour from Bulgarian penny buns (Boletus Edulis) is presented in Table 2. 
Table 2. Physico-chemical parameters of flour from Bulgarian Penny Buns (Boletus Edulis).

\begin{tabular}{|c|c|c|c|c|c|}
\hline $\begin{array}{c}\text { Moisture } \\
\text { content, } \%\end{array}$ & Protein,\% & Fat,\% & Carbohydrate,\% & Ash,\% & $\begin{array}{c}\text { Energy Value, Kcal/ } \\
\text { KJ }\end{array}$ \\
\hline 10.8 & 32.23 & 6.62 & 0.99 & 6.20 & $192.46 / 805.25$ \\
\hline
\end{tabular}

The results show a great amount of protein and fat, typical of the analysed product, which undoubtedly makes it extremely useful for vegan diets.

The analyses of the microbiological parameters provide the following data: total number of mesophilic aerobic and facultative anaerobic bacteria - $2.0 \times 10^{4}$; fungi $-6.0 \times 10^{2}$; lack of Salmonella sp., presence of Escherichia coli $-<10$; coagulase-positive staphylococci $<100$ and yeast $-<10$, i.e. all parameters studied are within acceptable levels. The results from the analysis proved that the product was not microbially contaminated, which allows us to believe that it was suitable for consumption.

The sorption isotherms and equilibrium moisture content of the flour from Bulgarian penny buns (Boletus Edulis) for adsorption and desorption are presented in Fig. 1 and Fig. 2. The experiment was conducted at three temperatures $-10{ }^{\circ} \mathrm{C}, 25^{\circ} \mathrm{C}$ and $40{ }^{\circ} \mathrm{C}$ and for eight water activities in the $0.10-0.90$ range.

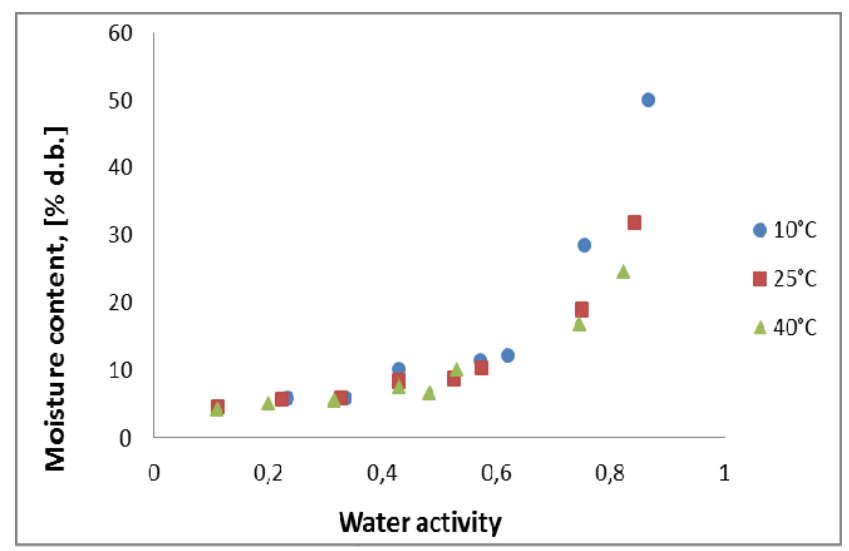

Fig. 1. Sorption isotherm for adsorption

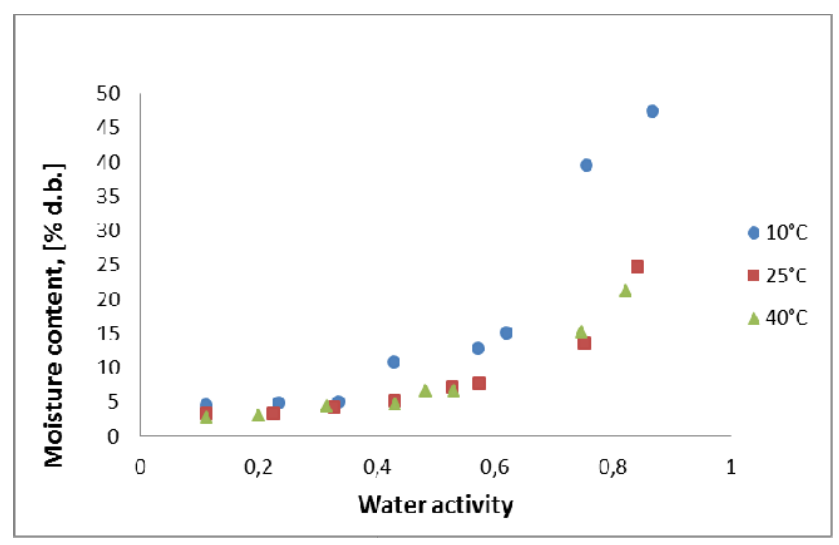

Fig. 2. Sorption isotherm for desorption 
The results show that the increase in temperature at a constant water activity is coupled with a decrease in equilibrium moisture content, a dependency pointed out by many authors for various food products [24 - 30]. The isotherms of the flour from Bulgarian penny buns are typical of Type III, using Brunauer's classification [31].

The statistical processing with the help of a non-linear regression program using the least squares method calculated the coefficients of the modified models applied in the analysis. The coefficients and values of the model suitability criteria - mean relative error P, \%, and standard error SEM - for adsorption and desorption are presented in Tables 3 and 4 .

Table 3. Model coefficients $(A, B, C)$, mean relative error (P, \%), and standard error (SEM) for adsorption.

\begin{tabular}{|c|c|c|c|c|c|}
\hline Model & $A$ & $B$ & $C$ & $P$ & $S E M$ \\
\hline Oswin & 12.042 & -0.1238 & 0.7732 & 24.94 & 2.28 \\
\hline Halsey & $\mathbf{2 . 6 8 0 5}$ & $\mathbf{- 0 . 0 0 6 4}$ & $\mathbf{1 . 2 8 8 4}$ & $\mathbf{1 0 . 6 3}$ & $\mathbf{2 . 2 4}$ \\
\hline Henderson & 0.00047 & 81.9008 & 1.1234 & 23.85 & 5.48 \\
\hline Chung-Pfost & 605.4333 & 0.1339 & 196.478 & 27.69 & 5.70 \\
\hline
\end{tabular}

Table 4. Model coefficients $(A, B, C)$, mean relative error (P, \%), and standard error (SEM) for desorption.

\begin{tabular}{|c|c|c|c|c|c|}
\hline Model & $A$ & $B$ & $C$ & $P$ & $S E M$ \\
\hline Oswin & 13.7821 & -0.2066 & 0.7474 & 28.18 & 3.98 \\
\hline Halsey & $\mathbf{2 . 1 6 6 5}$ & $\mathbf{- 0 . 0 1 6 5}$ & $\mathbf{1 . 0 3 8 9}$ & $\mathbf{1 0 . 5 0}$ & $\mathbf{2 . 2 9}$ \\
\hline Henderson & 0.00162 & 30.2908 & 0.9553 & 20.33 & 4.74 \\
\hline Chung-Pfost & 154.5974 & 0.1267 & 47.1888 & 23.09 & 5.06 \\
\hline
\end{tabular}

Taking into account the analysis of the results, we can recommend the modified Halsey for adsorption and desorption isotherm description of the flour from Bulgarian penny buns (Boletus Edulis). Only for this model are the mean relative error values below $10 \%$, the standard error possessing the lowest values.

The BET model was linearly transformed to calculate monolayer moisture content for the temperatures of $10{ }^{\circ} \mathrm{C}, 25^{\circ} \mathrm{C}$ and $40{ }^{\circ} \mathrm{C}$ and water activity within the aw $<0.5$ range. The results obtained are shown in Table 5 for both processes, adsorption and desorption.

Table 5. BET monolayer moisture content, \% d.b., at different temperatures $t$.

\begin{tabular}{ccc}
\hline$t\left({ }^{\circ} \mathrm{C}\right)$ & Adsorption & Desorption \\
\hline 10 & 3.18 & 4.37 \\
25 & 3.58 & 3.54 \\
40 & 3.99 & 3.15 \\
\hline
\end{tabular}

Analyzing the results in Table 5, we can conclude that with respect to the product studied flour from Bulgarian penny buns (Boletus Edulis) - the temperature affects the values of monolayer moisture content. At adsorption, the increase in temperature is accompanied by an increase in the values, within the $0.4-0.8 \%$ range. The exactly opposite process takes place for desorption - with the increase in temperature, monolayer moisture content values are lowered from 0.4 to $1.20 \%$. 


\section{Conclusion}

The data concerning flour particle size of Bulgarian penny buns, obtained via sieve analysis, show that the percentage of fractions with a particle size below $200 \mu \mathrm{m}$ is greatest $-63.1 \%$.

We also obtained data on the physico-chemical parameters of the flour from Bulgarian penny buns: Moisture content - $10.8 \%$; Protein - $32.23 \%$; Fat - $6.62 \%$; Carbohydrate $0.99 \%$; Ash - $6.20 \%$ and Energy Value - 192.46 / $805.25 \mathrm{Kcal} / \mathrm{KJ}$.

We determined the microbiological parameters of the flour from Bulgarian penny buns: total number of mesophilic aerobic and facultative anaerobic bacteria, fungi, Salmonella sp. Escherichia coli, coagulase-positive staphylococci and yeast, all of them being within acceptable limits.

We obtained the equilibrium isotherms of the flour from Bulgarian penny buns for the temperatures of $10^{\circ} \mathrm{C}, 25^{\circ} \mathrm{C}$ and $40{ }^{\circ} \mathrm{C}$ and water activities in the $0.1-0.9$ range.

We established that the isotherms belong to Type III, according to Brunauer's classification.

We also discovered that temperature affects the sorption capacity of the flour from Bulgarian penny buns. The increase in temperature for a constant water activity is coupled with the decrease in equilibrium moisture content.

In accordance with our criteria, the statistical processing makes us recommend the modified Halsey model for sorption isotherm description of the flour from Bulgarian penny buns.

The obtained monolayer moisture content values of the flour from Bulgarian penny buns are within the ranges of $3.18 \%$ d.b. - $3.99 \%$ d.b. for adsorption and $3.15 \%$ d.b. - 4.37 $\%$ d.b. for desorption.

\section{References}

1. J. Rotruck, A. L. Pope, H. E. Ganther, A.B. Swason, D.G. Hafeman, W.G. Hoestra, Science, 179, 588, (1973).

2. M. Montes-Bay'on, M. Jos'e D'raz Molet, E. Blanco Gonz'alez, A. Sanz-Medel, Talanta, 68, 1287-1293, (2006).

3. S.B. Goldhaber, RTP, 38 (2), 232-242, (2003).

4. A. Saleha, Y. Yaminia, M. Faraji, S. Shariatib, M. Rezaee, J. Chromatogr. B, 877, 1758-1764, (2009)

5. M. Navarro-Alarcon, C. Cabrera-Vique, Sci. Total Environ., 400 (1-3), 115-141, (2008).

6. L. Letavayová, V. Vlčkováb, J. Brozmanováa, Toxicology, 227 (1-2), 1-14, (2006).

7. AOAC, 960.39 (Washington, DC), 15 ed. AOAC. (1990)

8. B.S. Standard, Proteins, in Reglement (EO) №152/2009

9. B.S. Standard, Fat content, in BSS 6997:1984

10. B.S. Standard, Carbohydrates in BSS 7169:1989

11. No, ICC Standard, 104/1, (1-4), (1990)

12. Standard in Reglement 1169:2011. App. IVX, XV, (2011)

13. B.S. Standard, Escherichia coli, in (BSS) EN ISO 16649-2:2014

14. B.S. Standard, Salmonella spp., in (BSS) EN ISO 6579-1:2017

15. B.S. Standard, Coagulase-positive staphylococci, in (BSS) EN ISO 6888-1:2005, 
16. B.S. Standard, Mesophilic aerobic and facultative anaerobic bacteria, in (BSS) EN ISO 4833-2:2014,

17. B.S. Standard, Yeasts and fungi, (BSS) EN ISO 21527-2:2011

18. ASAE. Standart 245D.5. St. Joseph, Michigan.

19. C.-C. Chen, R.V. Morey. Transactions of the ASAE, 32 (3), 983-0990, (1989)

20. C.-C. Chen, R.V. Morey. Transactions of the ASAE, 32, 999-1006, (1989)

21. L. Bell, T. Labuza, AACC, 33-36, (2000)

22. A. Bogoeva, FPI Magazine, ISSN 1311-0179, 2, 27-30, (2018).

23. В. V. Bozadzhiev, A. P. Krasteva, Tsv. I. Gogova, Одеска Националъна Академия Харчових Технологий, Науковъ працъ, 30 (2), 34-39.

24. I. Dimov, ICTTE (Yambol, Bulgaria), I, ISSN 1314-9474, 479-485, (2013)

25. K. M. Majd, S. H. Karparvarfard, A. Farahnaky, K. Jafarpour, Food Biophys., 8 (1), 111, (2013).

26. M. Dupas-Langlet, J. Dupas, S. Samain, M. -I. Giardiello, V. Meunier, L. Forny, J. Food Eng., 184, 53-62, (2016).

27. A. G. Durakova, N. D. Menkov, J. Food Eng., 68 (4), 535-539, (2005).

28. P. Staudt, C. Kechinski, I. Tessaro, L. Marczak, R. d. P. Soares, N. Cardozo, J. Food Eng., 114 (1), 139-145, (2013).

29. Z. Yan, M. J. Sousa-Gallagher, F. A. Oliveira, J. Food Eng., 86 (3), 342-348, (2008).

30. A. Bogoeva, JCEA (to be published), (2020)

31. S. Brunauer, L. S. Deming, W. E. Diming, E. Troller, JACS, 62, 1723-1732, (1940). 